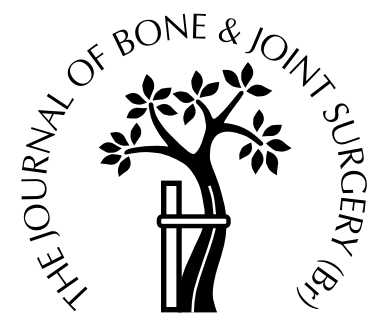

\title{
Circulating levels of insulin-like growth factor-1 and insulin-like growth factor binding protein-3 in patients with severe head injury
}

\author{
C. A. Beeton, R. A. Brooks, D. Chatfield, M. Human, N. Rushton \\ From the Orthopaedic Research Unit, University of Cambridge and Addenbrooke's \\ Hospital, Cambridge, England
}

$\mathbf{T}$ here is evidence to suggest that fractures heal more rapidly in patients with a head injury as a result of systemic factors released from the site of this injury. We have measured the circulating level of insulin-like growth factor-1 (IGF-1) and IGF binding protein-3 (IGFBP-3) in serum because of their known involvement in the stimulation of the activity of osteoblasts and the healing of fractures.

The serum level of IGF-1 was significantly lower in patients with both head injury and fracture and fracture only compared with that in healthy volunteers $(p<0.01$ and $p<0.02$, respectively). The level of IGFBP-3 was also significantly lower in patients with both head injury and fracture $(p<0.01)$.

Our findings showed, however, that the level of IGF-1 and IGFBP-3 varied from week to week in both the patients and healthy control subjects. These results indicate that the levels of circulating IGF-1 and IGFBP-3 are unlikely to be responsible for the altered healing of fractures seen in conjunction with head injury.

J Bone Joint Surg [Br] 2002;84-B:434-9.

Received 9 January 2001; Accepted after revision 25 June 2001

The healing of fractures of the long bones involves a complex series of cellular and biochemical events which are thought to arise primarily from the response of periosteal cells to disruption of the mechanical integrity of bone. ${ }^{1}$ There have been several reports that both the pro-

C. A. Beeton, PhD, Research Associate

R. A. Brooks, PhD, Research Associate

N. Rushton, FRCS, Director

Orthopaedic Research Unit, University of Cambridge, Addenbrooke's Hospital, Hills Road, Cambridge CB2 2QQ, UK.

D. Chatfield, Research Sister

Division of Anaesthesia, University of Cambridge, Addenbrooke's Hospital, Hills Road, Cambridge CB2 2QQ, UK.

M. Human, FRCS, Senior House Officer Plastic (Orthopaedic) Surgery c/o Plastic Surgery, Addenbrooke's Hospital, Hills Road, Cambridge CB2 2QQ, UK

Correspondence should be sent to Dr C. A. Beeton.

(C)2002 British Editorial Society of Bone and Joint Surgery 0301-620X/02/312027\$2.00 duction of callus and the rate of healing of fractures are increased by concomitant head injury. ${ }^{2-4}$ Spencer $^{3}$ compared fractures of the long bones at different sites in surviving adults with severe head injury with those in an age- and gender-matched control group without head injury. The greatest healing response was found in the patients with the most severe head injury and this directly correlated with an accelerated time of union of the fracture.

Perkins and Skirving ${ }^{2}$ compared two groups of patients with and without head injury, in whom fractures of the femoral shaft had been fixed by intermedullary nailing. The callus was significantly greater in the group with head injury and the mean time to radiological union was reduced.

The phenomenon of the altered healing of fractures in patients with head injury is also supported by the histological observations of the formation of ectopic bone ${ }^{3}$ and by heterotopic ossification in patients with traumatic paraplegia. ${ }^{5}$ Although healing of the fracture and the formation of bone in ectopic sites may differ clinically, both depend on the activity of osteogenic cells.

The release of a circulating osteogenic factor from the site of the head injury is a possible explanation for the connection between CNS injury and the formation of new bone at a distant location. Studies in vitro showing that both the proliferation of osteoblasts and the production of alkaline phosphatase are stimulated by serum from patients with head injury ${ }^{6-8}$ have provided evidence for this hypothesis. Other possible factors affecting the repair of fractures after head injury include altered neuronal activity and drug intervention.

Insulin-like growth factor-1 (IGF-1) is able to influence cells involved in the healing of fractures such as chondrocytes $^{9}$ and osteoblasts, ${ }^{10}$ and can also stimulate the synthesis of collagen in bone. ${ }^{10,11}$ In healthy individuals, serum levels of IGF-1 peak at puberty and decline with age. ${ }^{12,13}$ IGF-1 is bound to a family of insulin-like growthfactor-binding proteins (IGFBPs) ${ }^{12}$ which enhance or inhibit the proliferative and mitogenic effects of IGF-1 depending on the particular IGFBP, the cell type and the physiological milieu. $^{14,15}$ The action of the IGFBPs is partially dependent on the activity of protease ${ }^{16-19}$ and the resulting fragments have reduced affinity for IGFs. ${ }^{20}$ Dis- 
sociation of IGF from the binding complex allows free IGF to assume biological activity, ${ }^{21}$ but recent reports have described IGF-independent bioactivity of some IGFBP-3 fragments. 19,22

We chose to measure the circulating levels of IGF-1 and IGFBP-3 because they are thought to provide a good measure of the overall release and activity of growth hormone $(\mathrm{GH})^{23,24}$ which acts on osteoblasts and influences turnover of bone. ${ }^{25,26}$ The release of $\mathrm{GH}$ from the anterior pituitary is pulsatile and measurement of its production requires frequent sampling. ${ }^{27}$ Detailed measurement of the production of $\mathrm{GH}$ in patients with head injuries not directly involving the hypothalamic/pituitary axis has not been published, but there is evidence of both increased baseline secretion and of a loss of responsiveness to homeostatic control mechanisms. ${ }^{28,29}$

\section{Patients and Methods}

We selected patients using the following exclusion criteria: patients younger than 18 years or over the age of 75 years, diabetics, those on steroids or bisphosphonates and those with a previous head injury or bone-related problem. Table I gives the details of the patients in the study.

The Glasgow coma scale (GCS) ${ }^{30}$ and injury severity score (ISS) ${ }^{3 \mathrm{P}}$ were calculated for each patient on arrival and

Table I. Details of the patients, the control group and the healthy volunteers

\begin{tabular}{|c|c|c|c|}
\hline Case & $\begin{array}{l}\text { Age } \\
\text { (yrs) }\end{array}$ & Gender & Notes* \\
\hline \multicolumn{4}{|c|}{$\begin{array}{l}\text { Head injury } \\
\text { and fracture }\end{array}$} \\
\hline 1 & 54 & M & Haemorrhage, fracture skull and ribs, GCS 12 , ISS 17 \\
\hline 2 & 69 & M & Haemorrhage, fracture ribs and pelvis, GCS 10 , ISS 10 \\
\hline 3 & 20 & $\mathrm{~F}$ & Subdural bleeding, fracture skull, GCS 10, ISS 18 \\
\hline 4 & 54 & $\mathrm{M}$ & Diffuse HI, fracture ribs, tibia, fibula, clavicle, GCS 6 ISS 40 \\
\hline 5 & 19 & M & Closed head injury, fracture clavicle and spine, GCS 6 , ISS 22 \\
\hline 6 & 26 & $\mathrm{~F}$ & Diffuse head injury, fracture skull and femur, GCS 3, ISS 34 \\
\hline 7 & 19 & M & Haemorrhage, fracture skull, GCS 9, ISS 16 \\
\hline 8 & 20 & $\mathrm{~F}$ & $\begin{array}{l}\text { Frontal contusions and haemorrhage, fracture clavicle, } \\
\text { femur, metacarpals, GCS 3, ISS } 34\end{array}$ \\
\hline \multicolumn{4}{|c|}{ Head injury only } \\
\hline 9 & 55 & M & Unrousable due to alcohol, GCS 7, ISS 15 \\
\hline 10 & 25 & M & Haematoma, frontal contusions, GCS 7, ISS 11 \\
\hline 11 & 36 & M & Fell downstairs due to alcohol, GCS 9, ISS 17 \\
\hline 12 & 28 & M & Haematoma, GCS 7, ISS 43 \\
\hline 13 & 57 & $\mathrm{~F}$ & Haematoma, GCS 3, ISS 25 \\
\hline \multicolumn{4}{|c|}{ Fracture only } \\
\hline 14 & 21 & $\mathrm{~F}$ & Femur \\
\hline 15 & 43 & M & Femur \\
\hline 16 & 62 & $\mathrm{~F}$ & Femur \\
\hline \multicolumn{4}{|c|}{$\begin{array}{l}\text { Age- and gender- } \\
\text { matched controls }\end{array}$} \\
\hline 17 & 67 & $\mathrm{M}$ & Progressive peripheral neuropathy \\
\hline 18 & 20 & $\mathrm{~F}$ & Before breast reduction to correct asymmetry \\
\hline 19 & 52 & M & Ear, nose and throat department \\
\hline 20 & 18 & $\mathrm{~F}$ & Henoch Schonlein purpura, renal function tests \\
\hline 21 & 54 & M & Renal function tests, hypothyroidism \\
\hline 22 & 26 & M & Depression and hyperhidrosis \\
\hline 23 & 27 & $\mathrm{~F}$ & Dermatology clinic, generally atopic \\
\hline 24 & 18 & $\mathrm{M}$ & Severe acne \\
\hline 25 & 27 & $\mathrm{M}$ & Tests for Crohn's disease \\
\hline 26 & 26 & $\mathrm{~F}$ & Tests for gallstones \\
\hline 27 & 35 & M & Severe acne \\
\hline 28 & 20 & $\mathrm{M}$ & Shoulder and joint problems \\
\hline 29 & 54 & M & Non-allergic rhinitis follow-up appointment \\
\hline \multicolumn{4}{|c|}{ Healthy volunteers } \\
\hline 30 & 52 & $\mathrm{~F}$ & \\
\hline 31 & 31 & $\mathrm{~F}$ & \\
\hline 32 & 48 & $\mathrm{~F}$ & \\
\hline 33 & 27 & M & \\
\hline 34 & 42 & M & \\
\hline 35 & 27 & $\mathrm{~F}$ & \\
\hline 36 & 21 & $\mathrm{~F}$ & \\
\hline 37 & 58 & $\mathrm{~F}$ & \\
\hline 38 & 40 & $\mathrm{M}$ & \\
\hline 39 & 27 & M & \\
\hline
\end{tabular}

* GCS, Glasgow coma scale; ISS, injury severity score; HI, head injury. 
Table II. Statistical summary showing mean ( \pm sD) levels of IGF-1 and IGFBP-3 (pg/ml) in the various groups

\begin{tabular}{|c|c|c|c|c|}
\hline Group & IGF-1 $T_{1}{ }^{*}$ & IGF-1 mean $\dagger$ & IGFBP-3 $T_{1}+$ & IGFBP-3 mean $\S$ \\
\hline Head injury and fracture $(n=8)$ & $\begin{array}{l}136 \pm 57 \\
p=0.002\end{array}$ & $\begin{array}{l}147 \pm 36 \\
p=0.019\end{array}$ & $\begin{array}{l}2325 \pm 802 \\
p=0.003\end{array}$ & $\begin{array}{l}2760 \pm 441 \\
p=0.011\end{array}$ \\
\hline Head injury only $(\mathrm{n}=5)$ & $\begin{array}{l}142 \pm 80 \\
p=0.017\end{array}$ & $\begin{array}{l}116 \pm 92 \\
p=0.162\end{array}$ & $\begin{array}{l}3365 \pm 2087 \\
p=0.127\end{array}$ & $\begin{array}{l}3184 \pm 1263 \\
p=0.127\end{array}$ \\
\hline Fracture only $(n=3)$ & $\begin{array}{l}216 \pm 116 \\
p=0.954\end{array}$ & $\begin{array}{l}216 \pm 116 \\
p=0.613\end{array}$ & $\begin{array}{l}3758 \pm 965 \\
p=0.207\end{array}$ & $\begin{array}{l}3758 \pm 965 \\
p=0.407\end{array}$ \\
\hline Age- and gender-matched control subjects $(\mathrm{n}=13)$ & $\begin{array}{l}259 \pm 104 \\
p=0.943\end{array}$ & $\begin{array}{l}259 \pm 104 \\
p=0.442\end{array}$ & $\begin{array}{l}4297 \pm 1377 \\
p=0.480\end{array}$ & $\begin{array}{l}4297 \pm 1377 \\
p=0.823\end{array}$ \\
\hline Apparently healthy control subjects $(n=10)$ & $231 \pm 100$ & $208 \pm 76$ & $4982 \pm 1823$ & $4488 \pm 1490$ \\
\hline \multirow[t]{2}{*}{ Age in years } & -2.8 & -2.6 & +1.73 & -19 \\
\hline & $\mathrm{p}=0.001$ & $\mathrm{p}=0.002$ & $\mathrm{p}=0.912$ & $\mathrm{p}=0.143$ \\
\hline \multirow[t]{2}{*}{$M: F(n=24: n=15)$} & +73 & +62 & -722 & -451 \\
\hline & $\mathrm{p}=0.012$ & $\mathrm{p}=0.021$ & $\mathrm{p}=0.185$ & $\mathrm{p}=0.300$ \\
\hline
\end{tabular}

at intubation as part of the assessment of the patient. The GCS is used to assess the level of consciousness in patients with head injuries using three subscales: eye opening, verbal response and motor response. The scores range from 3 to 15 in which 15 indicates a fully alert, orientated person and 3 is indicative of a deep coma. The ISS is used to grade all injuries. The body is divided into seven regions and a severity code is used to describe individual injuries in six categories. The highest ISS score obtainable is 75 .

Ethical approval was obtained from the local research Ethics Committee and, following written consent from the patient or next of kin, $20 \mathrm{ml}$ blood were obtained from eight patients with head injury and fracture $(5$ male, 3 female), five with head injury only ( 4 male, 1 female) and three with fracture only ( 2 male, 1 female) within the first few hours of admission to hospital. Weekly samples were obtained from patients with head injury for the duration of their stay in hospital. Initial data points were available for all subjects and univariate analysis of variance with age and gender as covariants was performed on these data to assess the differences between groups. Blood was taken from 13 age- and gender-matched patients ( 9 male, 4 female) attending outpatient appointments and additionally from ten apparently healthy volunteers (4 male, 6 female). All blood samples were allowed to clot for 30 minutes at room temperature and spun at $3000 \mathrm{rpm}$ for ten minutes. Serum was removed and stored at $-70^{\circ} \mathrm{C}$ until use.

Serum was thawed at room temperature and mixed well before use. The serum levels of IGF-1 and IGFBP-3 were measured by enzyme-linked immunosorbant assay (ELISA) (Diagnostic Systems Laboratories Inc, Webster, Texas) following the manufacturer's instructions. Two methods were used for the measurement of IGF-1. Both used sandwichtype immunoassay and in one an additional dissociation step was included which had been optimised to separate
IGF from the IGFBPs. The IGFBP-3 ELISA detects both fragments of IGFBP-3 and intact IGFBP-3. Sodium dodecyl sulphate-polyacrylamide gel electrophoresis (SDSPAGE) and Western blotting were performed to determine if the IGFBP-3 detected was mostly intact or fragmented. ${ }^{32}$ The initial serum samples from patients with head injury and fracture were compared with those of healthy volunteers by protein separation on a $10 \%$ SDS polyacrylamide non-reducing gel. The proteins were transferred on to nitrocellulose membrane (Sigma) by electroblotting and nonspecific sites blocked overnight with $1 \%$ bovine serum albumin (Sigma). Primary antibody (Diagnostic Systems Laboratories Inc) was applied at 1/1000 for four hours, membrane washed, and alkaline-phosphatase-labelled rabbit anti-goat IgG (Vector Laboratories Inc, California) at 1/1000 applied. The membrane was developed with 5bromo-4-chloro-3-indolyl phosphate nitroblue tetrazolium substrate (Vector Laboratories) and air dried.

Statistical analysis. This was performed using SPSS for Windows Version 9.0 (SPSS Inc, Chicago, Illinois). Blood samples were obtained from patients on a weekly basis limited by their duration of stay in hospital. The level of IGF-1 and IGFBP-3 is affected by age and gender and therefore univariate analysis of variance was performed with age and gender as covariants thus controlling for these factors in the model. All groups were compared with the volunteers. Additionally, the group of apparently healthy individuals provided weekly blood samples to determine week-to-week variations in IGF-1 and IGFBP-3. Table II summarises the statistical data.

\section{Results}

Both IGF-1 ELISAs were highly comparable (Pearson correlation, $\left.\mathrm{r}^{2}=0.978, \mathrm{p}<0.001\right)$. Because of the close 
correlation of the two methods, further measurements of IGF-1 were performed using the extraction method.

Age and gender had a significant effect on IGF-1 but less on IGFBP-3 (Table II). With increasing age, the level of IGF-1 decreased and this remained significant when comparing both the initial time points and the mean value. The data also show that males had a significantly higher circulating level of IGF-1 irrespective of the study group.

The circulating level of both IGF-1 and IGFBP-3 was significantly lower in patients with both head injury and fracture at the initial time point corrected for age and gender and this remained significant when all time points were considered (Table II and Fig. 1). The level of IGF-1 and IGFBP-3 in patients with head injury was also lower than those of the control group, although only the data obtained from the initial time point for IGF-1 were significant (Table II). When comparing patients with head injury with and without fracture with their age- and gendermatched controls, the Wilcoxon signed-rank test gave an exact two-tailed $\mathrm{p}$ value for IGF-1 of 0.02 and for IGFBP-3 of 0.03 .

The level of IGF-1 and IGFBP-3 were measured in apparently healthy volunteers weekly. Fluctuation in the circulating level of both IGF-1 and IGFBP-3 was found, but neither showed a consistent trend.

No significant differences were found between IGF-1 samples obtained from age- and gender-matched patients attending outpatient phlebotomy clinics and the volunteers at either the initial time point or when the mean values were considered.
Western blotting revealed a protein of approximately $45 \mathrm{kD}$ and two smaller proteins of approximately $34 \mathrm{kD}$ and $35 \mathrm{kD}$. No other fragments were observed. There were no differences in the pattern of fragments found in serum obtained from patients with head injury and fracture compared with that of the volunteers.

\section{Discussion}

The results show that the circulating level of IGF-1 is significantly lower in patients with head injury and fracture and head injury only compared with that in apparently healthy individuals.

It has been shown in both rats and obese males that nutritional status influences the serum concentration of IGF- $1^{33,34}$ and it has been postulated that alteration in the nutritional status is a potent regulator of this. Van de Berghe, de Zegher and Lauwers Veldhuis ${ }^{35}$ suggested that in critically ill patients, although not with head injury, the serum IGF-1 level correlated well with conventional nutritional indices, such as nitrogen balance.

Similarly, Ross, Miell and Freeman ${ }^{36}$ reported that the level of IGF-1 was lower in critically ill patients compared with a control group, but their study suggested that this was not altered by nutritional status. They hypothesised that there is an adaptive change in critically ill patients away from the indirect effects of GH (stimulation of IGF-1 production and anabolism) and towards the direct effects (lipolysis and insulin antagonism) which increases the availability of energy substrates. They studied critically ill

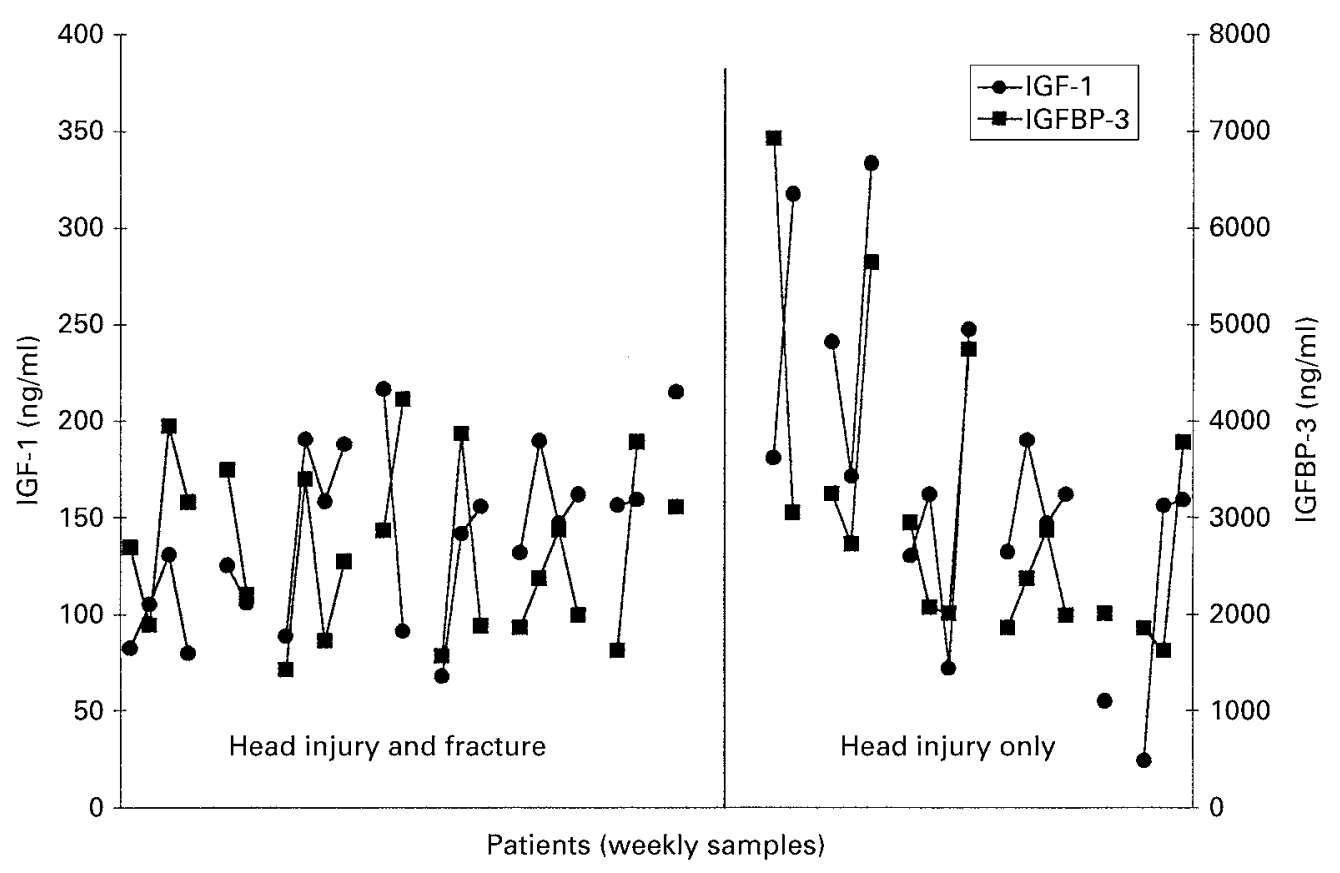

Fig. 1

Serial levels of IGF-1 and IGFBP-3 in serum obtained from eight patients with head injury and fracture and five with head injury only. Linked points represent weekly samples from individual patients. 
patients requiring major abdominal surgery and excluded patients with head injury. It is possible, however, that a similar response occurs in patients with head injury and this cannot be discarded as a possible explanation for the results presented in our study.

Of our 13 patients with head injury, ten received intravenous dopamine in varying doses $(2.7$ to $9.5 \mathrm{~g} / \mathrm{kg} / \mathrm{min}$ ) and for a variety of days, but in none did this exceed seven. Dopamine has been shown to affect the level of IGF-1 in critically ill patients ${ }^{35,37,38}$ although none of the reports involved patients with head injury. Particularly, Van de Berghe et $\mathrm{al}^{35}$ showed that prolonged infusion of dopamine for 83 to 296 hours was associated with a low concentration of IGF-1 compared with no dopamine or only a brief infusion for 15 to 21 hours. Although the data presented in our study show that IGF-1 was suppressed in patients with head injury compared with healthy volunteers, it is unlikely to be a result of the infusion of dopamine. The initial blood sample was taken within hours of the admission of the patient and before receiving drugs such as dopamine.

Our results show that males have a significantly higher level of circulating IGF-1 than females at initial time points and that this significantly decreases with age irrespective of gender. This significance remained when data from all time points were considered. Yu, Mistry and Nicar ${ }^{39}$ showed that the level of IGF-1 was slightly higher in females than in males. Their data were obtained from pooled samples of serum and EDTA plasma and therefore cannot be directly compared with our data which were obtained from serum samples. Our findings reflect previous reports that the level of IGF-1 decreases with age. ${ }^{40-42}$

The circulating level of IGFBP-3 was significantly lower in patients with head injury and fracture compared with that in volunteers at the initial time point and this remained significant when all time points were considered. None of the other groups showed significantly different values when compared with volunteers.

In order to determine whether the level of IGF-1 and IGFBP-3 fluctuated on a weekly basis repeated samples were taken from seven volunteers, in four for three weeks and in three for two weeks. The circulating level of both IGF-1 and IGFBP-3 varied widely and without any trend, indicating that the level of these analytes in blood does not remain constant. Stratakis, Mastorakos and Magiakou ${ }^{43}$ measured the level of IGF-1 and IGF-2 in young adults of normal and tall stature and found that they had large circadian variation with a nocturnal surge, when measured in "acid-ethanol extracted" plasma. They found that measurements of IGF-1 in "unextracted" samples failed to reveal the same circadian variation in any of the subjects studied. The weekly variation in the circulating levels of IGF-1 and IGFBP-3 in the healthy volunteers in our study is unlikely to be explained by circadian variation because each sample was obtained within a 90-minute period around midday.

Western blotting revealed three proteins of different weights in serum obtained from apparently healthy volun- teers and patients with head injury and fracture. The largest of these was approximately $45 \mathrm{kD}$. Op De Beeck et $\mathrm{al}^{44}$ assessed the pattern of IGFBP-3 fragments in normal human serum using Western blotting and enhanced chemiluminescence. In our study, proteins of similar sizes, also observed by Op De Beeck et al, ${ }^{44}$ were found and there were no differences between patients with head injury and fracture compared with control subjects. The largest protein is likely to be the glycosylated protein since its reported size is approximately 44 to $48 \mathrm{kD}$ while the smaller proteins are likely to be the non-glycosylated proteins. ${ }^{45}$

Our study has shown that the circulating level of IGF-1 is significantly lower in patients with head injury and fracture and head injury only, and is significantly higher in males than in females. In addition, the level of IGFBP-3 is significantly lower in patients with head injury and fracture compared with healthy individuals and the circulating level of IGF-1 and IGFBP-3 in healthy volunteers varied from week to week. These results suggest that IGF-1 and IGFBP-3 are not the circulating factors responsible for the altered fracture healing, but this does not eliminate a role for IGF-1 and IGFBP-3 at the tissue level. Andrew et $\mathrm{al}^{46}$ reported osteoblastic and non-hypertrophic chondrocytic expression of mRNA for IGF-1 at the stage of formation of both bone and cartilage in the normal healing of fractures in man. If the secretion of $\mathrm{GH}$ is increased in patients with head injury it may be acting to increase IGF-1 locally at the site of the fracture. The current results, however, showing a decrease in the release of IGF-1 into the circulation may indicate a lack of responsiveness of GH. It is clear that the search for a circulating factor responsible for the altered healing of fractures seen after head injury continues.

We wish to thank Mrs Joy Williamson and colleagues in the Outpatient Phlebotomy Department, Addenbrooke's Hospital, Cambridge for their cooperation in recruiting age- and gender-matched control subjects for this study. We also wish to thank Dr Jonathon Coles and Mrs Diana Day for their help in recruiting patients with head injuries, and are grateful to Dr Brian Tom at the University of Cambridge Centre of Applied Medical Statistics for statistical advice.

This work was supported by the AO/ASIF foundation, The Wishbone Trust and Addenbrooke's Charities Committee.

No benefits in any form have been received or will be received from a commercial party related directly or indirectly to the subject of this article.

\section{References}

1. Oni OOA. Callus formation during diaphyseal fracture repair. Orthopaedics 1996;4:269-77.

2. Perkins R, Skirving AP. Callus formation and the rate of healing of femoral fractures in patients with head injuries. J Bone Joint Surg [Br] 1987;69-B:521-4.

3. Spencer RF. The effect of head injury on fracture healing: a quantitative assessment. J Bone Joint Surg [Br] 1987;69-B:5258.

4. Stone MH, Newman RJ, Mukherjee SK. Accelerated fracture union in association with severe head injury. $J$ Bone Joint Surg $[\mathrm{Br}]$ 1987;69-B:493.

5. Smith R, Triffit JT. Bones in muscles: the problem of soft tissue ossification. Q J Med 1986;61:985-90.

6. Bidner SM, Rubins IM, Desjardins JV, Zukor DJ, Goltzman D. Evidence for a humoral mechanism for enhanced osteogenesis after head injury. J Bone Joint Surg [Am] 1990;72-A:1144-9. 
7. Kurer MHJ, Kokher MA, Dandhona P. Sera from paraplegics with heterotopic ossification and patients with fractures and head injury stimulate human osteoblasts in vitro. J Bone Joint Surg [Br] 1991;73-B, Suppl 1:59.

8. Renfree KJ, Banovac K, Hornicek FJ, et al. Evaluation of serum osteoblast mitogenic activity in spinal cord and head injury patients with acute heterotopic ossification. Spine 1994;19:740-6.

9. Vetter U, Zapf J, Heit W, et al. Human fetal and adult chondrocytes: effects of insulin and growth hormone on clonal growth. J Clin Invest 1986;77:1903-8.

10. Kasperk CH, Wergedal JE, Mohan S, et al. Interactions of growth factors present in bone matrix with bone cells: effects on DNA synthesis and alkaline phosphatase. Growth factors 1990;3:147-58

11. Wergedal J, Mohan S, Lundy M, Baylink D. Skeletal growth factor and other growth factors known to be present in bone matrix stimulate proliferation and protein synthesis in human bone cells. $J$ Bone Miner Res 1990;5:179-86.

12. Jones JI, Clemmons DR. Insulin-like growth factors and their binding proteins: biological actions. Endocrine Rev 1995;16:3-34.

13. Vance HL. Growth hormone for the elderly? New Engl J Med 1990;323:52-54.

14. Rutanen EM, Pekonen F, Mäkinen T. Soluble $34 \mathrm{~K}$ binding protein inhibits the binding of insulin-like growth factor-I to its cell receptors in human secretory endometrium: evidence for autocrine/paracrine regulation of growth factor action. J Clin Endocrinol Metab 1988;66:173-80.

15. Elgin R, Busby WH Jr, Clemmons D. An insulin-like growth factor (IGF) binding protein enhances the biologic response to IGF1. Proc Nat Acad Sci USA 1987;84:3254-8.

16. Giudice LC, Farrell E, Pham H, Lamson G, Rosenfeld RG. Insulin-like growth factor binding proteins in maternal serum throughout gestation and in the puerperium: effects of a pregnancyassociated serum protease activity. J Clin Endocrinol Metab 1990;71:806-16.

17. Hossenlopp $\mathbf{P}$, Segovia B, Lassarre $\mathbf{C}$, et al. Evidence of enzymatic degradation of insulin-like growth factor-binding proteins in the $150 \mathrm{~K}$ complex during pregnancy. J Clin Endocrinol Metab 1990;71:797-805

18. Bang P. Serum proteolysis of IGFBP-3. Pro Growth Factor Res 1995;6:285-92.

19. Lalou C, Lassarre C, Binoux M. A proteolytic fragment of insulinlike growth factor (IGF) binding protein-3 that fails to bind to IGFs inhibits the mitogenic effects of IGF-1 and insulin. Endocrinology 1996;137:3206-12.

20. Gargosky S, Pham HM, Wilson $K$, et al. Measurement and characterisation of insulin-like growth factor binding protein-3 in human biological fluids: discrepancies between radioimmunoassay and ligand blotting. Endocrinology 1992;131:3051-60.

21. Clemmons DE, Elgin RG, Han VK, et al. Cultured fibroblast monolayers secrete a protein that alters the cellular binding of somatomedin-C/insulin-like growth factor-1. J Clin Invest $1986 ; 77: 1548-56$

22. Booth B, Boes M, Bar RS. IGFBP-3 proteolysis by plasmin, thrombin, serum: heparin binding, IGF binding and structure of fragments. Am J Physiol 1995;34-E:465-70.

23. Blum WF, Ranke MB, Kietzmann $K$, et al. A specific radioimmunoassay for the growth hormone $(\mathrm{GH})$-dependent somatomedin binding protein: its use for diagnosis of GH deficiency. J Clin Endocrinol Metab 1990;70:1292-8.

24. Lee PDK, Rosenfeld RG. Clinical utility of insulin-like growth factor assays. Pediatrician 1987;14:154-61.

25. Slootweg MC, van Buul-Offers SC, Herrmann-Erlee MPM, Duursma SA. Direct stimulatory effect of growth hormone on DNA synthesis of fetal chicken osteoblasts in culture. Acta Endocrinol (Copenh) 1988;118:294-300.
26. Ernst M, Froesch E. Growth hormone dependant stimulation of osteoblast-like cells in serum-free cultures via local synthesis of insulin-like growth factor I. Biochem Biophys Res Commun $1988 ; 151: 142-7$

27. Hartman ML, Faria AC, Vance ML, et al. Temporal structure of in vivo growth hormone secretory events in humans. Am J Physiol 1991;260:101-10.

28. Sazbon L, Sack J, Najenson C, Lunenfeld B. Growth hormone and periarticular new bone formation: a causal relationship?: a preliminary communication. Scand J Rehab Med 1982;15:43-6.

29. Hackl JM, Gottardis M, Wieser C, et al. Endocrine abnormalities in severe traumatic brain injury: a clue to prognosis in severe cranio-cerebral trauma. Intensive Care Med 1991;17:25-9.

30. Greenspan L, McLellan B, Greig H. Abbreviated injury scale and injury severity score: a scoring chart. J Trauma 1985;25:60-4.

31. Hickey J. Assessment of neurological signs. In: The clinical practice of neurological and neurological nursing. Third edition. Lippincott Company, 1992:115-6.

32. Hossenlopp P, Seurin D, Segovia-Quinson B, Hardouin S, Binoux M. Analysis of serum insulin-like growth factor binding proteins using Western blotting: use of the method for titration of the binding proteins and competitive binding studies. Analyt Biochem 1986;154:138-43.

33. Clemmons D, Klibanski A, Underwood $\mathbf{L}$, et al. Reduction of plasma immunoreactive somatomedin $\mathrm{C}$ during fasting in humans. $J$ Clin Endocrinol Metab 1981;53:1247-50.

34. Maes M, Underwood LE, Ketelslegers J. Plasma somatomedin-C in fasted and refed rats: close relationship with changes in liver somatogenic but not lactogenic binding sites. J Endocrinol 1983;97:243-52.

35. Van den Berghe G, de Zegher FP, Lauwers $P$, Veldhius J. Growth hormone secretion in critical illness: effect of dopamine. J Endocrinol Metab 1994;79:1141-6.

36. Ross R, Miell J, Freeman E, et al. Critically ill patients have high basal growth hormone levels with attenuated oscillatory activity associated with low levels of insulin-like growth factor-1. Clin Endocrinol 1991;35:47-54.

37. Van den Berghe G, de Zegher F. Anterior pituitary function during critical illness and dopamine treatment. Crit Care Med 1996;24:1580-90.

38. Gibson F, Hinds C. Growth hormone and insulin-like growth factors in critical illness. Intensive Care Med 1997:369-78.

39. Yu H, Mistry J, Nicar M, et al. Insulin-like growth factors (IGF-I, free IGF-I and IGF-II) and insulin-like growth factor binding proteins (IGFBP-3, IGFBP-3, IGFBP-6 and ALS) in blood circulation. J Clin Lab Analy 1999;13:166-72.

40. Ross P, Knowlton W. Rapid bone loss is associated with increased levels of biochemical markers. J Bone Miner Res 1998;13:297-302.

41. Daughaday W, Rotwein P. Insulin-like growth factor Is and II: peptide, messenger ribonucleic acid and gene structures, serum and tissue concentrations. Endo Rev 1989;10:68-91.

42. Rosen CJ, Donahue LR, Hunter SJ. Insulin-like growth factors and bone: the osteoporosis connection. Proc Soc Exp Biol Med 1994;206:83-102.

43. Stratakis C, Mastorakos G, Magiakou M et al. 24-hour secretion of growth hormone $(\mathrm{GH})$, insulin-like growth factors-I and II (IGF-I, -II), prolactin (PRL) and thyrotropin (TSH) in young adults of normal and tall stature. Endocrine Res 1996;22:261-76.

44. Op De Beeck L, Verlooy J, Buul-Offers S, Du Caju M. Detection of serum insulin-like growth factor binding proteins on Western ligand blots by biotinylated IGF and enhanced chemiluminescence. $J$ Endocrinol 1997; $154: 1-5$

45. Spratt SK, Tatsuno GP, Yamanaka MK, et al. Cloning and expression of human insulin-like growth factor binding protein-3. Growth Factors 1990;3:63-72.

46. Andrew JG, Hoyland J, Freemont AJ, Marsh D. Insulinlike growth factor gene expression in human fracture callus. Calcif Tissue Int 1993;53:97-102. 